\title{
THE EFFECT OF INTELLECTUAL CAPITAL AND ISLAMICITY PERFORMANCE INDEX TO THE PERFORMANCE OF ISLAMIC BANK IN INDONESIA 2010- 2014 PERIODS
}

\author{
Pandu Dewanata \\ Faculty of Economy State University of Jakarta \\ Email: pdewanata13@gmail.com \\ Hamidah \\ Faculty of Economy State University of Jakarta \\ Email: hamidahsam@gmail.com \\ Gatot Nazir Ahmad \\ Faculty of Economy State University of Jakarta \\ Email: ahmad72nazir@gmail.com
}

\begin{abstract}
The purpose of this research is to know the influence of intellectual capital and islamicity performance index by proxy is profit-sharing ratio, zakat performance ratio, and equitable distribution ratio on performance of Islamic bank in Indonesia in the period 2010-2014. The data used in this research is financial statement of 11 Islamic bank in Indonesia 2010-2014 periods. Regression model using panel data with Fixed Effect Model. The result of this research is intellectual capital and zakat performance ratio has significant and positif impact on ROA, while equitable distribution ratio has not significant impact on ROA, and profit sharing ratio has significant and positif impact on ROA.
\end{abstract}

Keyword: Islamic bank, Performance, Intellectual Capital, Islamicity Performance Index 


\section{PENDAHULUAN}

Di era globalisasi seperti saat ini, dunia bisnis terus mengalami perkembangan yang pesat. Perusahaan dituntut melakukan pembaharuanpembaharuan untuk dapat bersaing dengan cara berfikir secara global namun tetap bertindak secara lokal, dan melakukan inovasi dalam teknologi (Daud dan Amri, 2008:213).

Kemajuan teknologi informasi, ilmu pengetahuan dan persaingan yang ketat, memaksa perusahaan merubah strateginya dari bisnis yang berdasarkan tenaga kerja (labor based business) ke arah bisnis yang berdasarkan pada ilmu pengetahuan (knowledge based business). Seiring dengan perubahan ekonomi yang berbasis pengetahuan, membuat kemakmuran suatu perusahaan bergantung pada suatu penciptaan transformasi dan kapitalisasi dari pengetahuan itu sendiri (Sawarjuwono, 2003:36). Perubahaan tersebut membuat intellectual capital mendapat perhatian lebih sebagai modal perusahaan untuk dapat bersaing. Dalam Certified International Management Accounting (CIMA) pada tahun 2001 menyatakan bahwa intellectual capital merupakan kepemilikian pengetahuan dan pengalaman, pengetahuan profesional dan keahlian, hubungan baik, dan kapasitas teknologi yang dapat memberikan keunggulan kompetitif bagi perusahaan (Fitriyeni dan Yurniwati, 2015:212).

Pada tahun 1998 dan 2000, Pulic mengusulkan Value Added Intellectual Coefficient (VAIC ${ }^{\mathrm{TM}}$ ) sebagai suatu model pengukuran intellectual capital. Model ini digunakan untuk mengukur kemampuan perusahaan dalam menciptakan efisiensi dari nilai tambah pada aset berwujud dan aset tak berwujud yang dimiliki perusahaan sebagai hasil dari kemampuan intelektualnya. Terdapat 3 komponen utama dalam VAICTM, yaitu physical capital (Value added Capital Employed VACA), human capital (Value Added Human Capital - VAHU), dan structural capital (Structural Capital Value Added - STVA).

Sudah banyak penelitian yang dilakukan untuk mengetahui pengaruh intellectual capital terhadap kinerja perusahaan. Salah satu sampel penelitian yang sering digunakan adalh industri perbankan, karena menurut Firer dan Williams, 
perbankan memiliki teknologi komunikasi yang lebih intensif, sehingga intellectual capital lebih sering digunakan dalam menjalankan aktivitasnya dibandingkan aset fisik pada perusahaan manufaktur (Melani et. al, 2013:283). Di Indonesia dalam kebijakan mengenai perbankan menganut dual banking system, yaitu pelaksanaan perbankan yang diatur dalam berbagai peraturan perundangundangan yang berlaku dengan menyelenggarakan dua sistem perbankan, bank konvensional dan bank syariah secara berdampingan (Anshori, 2007:33). Bank syariah menjadi objek yang sangat menarik untuk diteliti, karena Indonesia merupakan negara dengan penduduk muslim terbesar di dunia, dan perkembangan bank syariah di Indonesia terus mengalami kemajuan yang cukup pesat.

Perbankan syariah sebagai suatu lembaga keuangan yang bergerak berdasarkan prinsip-prinsip syariah tentunya memiliki karakteristik yang berbeda dengan perusahaan lain dalam orientasi kinerjanya. Oleh karena itu, kinerja perbankan syariah selain diukur dengan metode konvensional, juga harus diukur dengan metode yang beriorientasi pada tujuan syariah. Hameed et. al. (2004) menyajikan sebuah alternatif pengukuran kinerja keuangan untuk bank syariah, yaitu Islamicity Performance Index. Indeks ini bertujuan untuk mengetahui apakah kinerja keuangan perbankan syariah telah dijalankan sesuai dengan prinsip-prinsip syariah.

Penelitian yang dilakukan oleh Ousama dan Fatima (2015) menyatakan bahwa setiap komponen utama dalam intellectual capital mempengaruhi kinerja bank syariah dengan profitabilitas sebagai tolak ukur kinerjanya, namun dengan tingkat yang bervariasi. Falikhatun dan Assegaf (2012) melakukan penelitian tentang implementasi prinsip syairah dan menyimpulkan bahwa perbankan syariah yang telah mengimplementasikan prinsip-prinsip syariah dapat meningkatkan kesehatan finansialnya dan tidak menyebabkan sistem keuangan mengkhawatirkan atau bahkan bangkrut. Selanjutnya Maisaroh (2015) meneliti tentang pengaruh intellectual capital dan islamicity performance index terhadap profitabilitas perbankan syariah di Indonesia. Hasilnya menunjukkan bahwa intellectual capital dan islamicity performance index secara simultan berpengaruh positif signifikan terhadap return on assets (ROA). 


\section{Rumusan Masalah}

Berdasarkan penjelasan latar belakang diatas, maka dapat diidentifikasikan masalah-masalah dalam penelitian ini adalah sebagai berikut:

1. Apakah intellectual capital berpengaruh terhadap kinerja Bank Umum Syariah di Indonesia periode 2010-2014?

2. Apakah islamicity performance index berpengaruh terhadap kinerja Bank Umum Syariah di Indonesia periode 2010-2014?

3. Apakah intellectual capital dan islamicity performance index berpengaruh secara bersama-sama terhadap kinerja Bank Umum Syariah di Indonesia periode 2010-2014?

\section{Tujuan Penelitian}

Secara umum penelitian ini bertujuan sebagai berikut:

1. Untuk mengetahui pengaruh intellectual capital terhadap kinerja Bank Umum Syariah di Indonesia periode 2010-2014.

2. Untuk mengetahui pengaruh islamicity performance index terhadap kinerja Bank Umum Syariah di Indonesia periode 2010-2014.

3. Untuk mengetahui intellectual capital dan islamicity performance index secara bersama-sama terhadap kinerja Bank Umum Syariah di Indonesia periode 2010-2014.

\section{KAJIAN TEORI}

\section{Stakeholder Theory}

Stakeholder adalah kelompok-kelompok yang terlibat langsung dengan suatu perusahaan seperti karyawan, pelanggan, pemasok, kreditur, pemilik, dan pihak-pihak lainnya yang terlibat langsung (Gitman dan Zutter, 2011:13). Pendekatan stakeholder muncul pada pertengahan tahun 1980-an. Menurut Freeman dan McVea (2001, dalam Hermawan dan Rochman, 2015:74) keinginan untuk membangun kerangka kerja yang cepat dalam menanggapi setiap masalah yang dihadapi menjadi latar belakang munculnya pendekatan ini. 
Menurut Prasetiyo (2014:11) menyatakan bahwa semua stakeholder memilki hak untuk diperlakukan dengan adil oleh perusahaan. Selain itu, menurut Deegan (2004, dalam Hermawan dan Rochman, 2015:73) stakeholder theory menyatakan bahwa semua stakeholder mempunyai hak untuk memperoleh informasi mengenai aktifitas perusahaan yang mempengaruhi mereka. Meek dan Gray (1988, dalam Ulum, 2008:3) menjelaskan bahwa dalam stakeholder theory laba akuntansi merupakan ukuran return bagi pemegang saham (shareholder), sedangkan value added merupakan ukuran yang lebih akurat yang diciptakan oleh stakeholder dan didistribusikan kepada stakeholder yang sama. Dengan demikian keduanya dapat menjelaskan kekuatan teori stakeholder dalam pengukuran kinerja perusahaan (Ulum et. al., 2008:3).

\section{Resource Based Theory}

Resource Based Theory (RBT) menjelaskan bahwa suatu perusahaan akan memiliki suatu keunggulan kompetitif dan berdaya saing tinggi apabila perusahaan tersebut mampu memanfaatkan secara efektif keberagaman sumber daya yang dimiliki, baik yang berwujud maupun tak berwujud (Mwailu dan Mercer, 1983; Wernefelt, 1984; Rumelt, 1984, dalam Motilewa et. al., 2015:98). Fokus utama RBT adalah sumber daya yang mampu menghasilkan keunggulan kompetitif yang berkelanjutan. Terdapat empat karakteristik sumber daya dapat dikatakan sebagai sumber keunggulan kompetitif yang berkelanjutan, yaitu berharga, langka, tidak dapat ditiru, dan non-subtitusi.

\section{Intellectual Capital}

Menurut Sangkala (2006:7), intellectual capital merupakan materi intelektual yang terdapat dalam diri karyawan seperti pendidikan dan pengalaman, dan juga aset perusahaan yang berbasis pengetahuan atau hasil dari proses transformasi pengetahuan yang dapat berwujud aset intelektual perusahaan. Intellectual capital dipercaya telah menjadi sumber daya yang penting dalam menciptakan keunggulan kompetitif dan meningkatkan kinerja bisnis. Pengelolan intellectual capital dapat diukur dengan sinergi tiga komponen, yaitu human capital (HC), structural capital (SC) dan capital employed (CE). 
Pulic (1998) mengajukan sebuah model pengukuran intellectual capital yang dia namakan Value Added Intellectual Coefficient (VAIC ${ }^{\text {TM}) . ~ M o d e l ~ i n i ~}$ digunakan untuk mengukur kemampuan perusahaan dalam menciptakan efisiensi dari value added (VA) pada aset berwujud dan aset tak berwujud yang dimiliki perusahaan sebagai hasil dari kemampuan intelektualnya. Komponen utama dari VAICTM adalah Value Added Capital Employed (VACA = VA/CE), Value Added Human Capital $(\mathrm{VAHU}=\mathrm{VA} / \mathrm{HC})$, dan Structural Capital Value Added $(\mathrm{STVA}=$ SC/VA).

$$
\text { VAIC }=\text { VACA + VAHU + STVA }
$$

\section{Islamicity Performance Index}

Perbankan syariah memilki sistem yang sama seperti halnya aspek-aspek lain dari pandangan hidup Islam. Menurut Algoud dan Lewis (2001, dalam Falikhatun dan Assegaf, 2012:248) menyimpulkan bahwa tujuan utama perbankan dan keuangan Islam dari perspektif Islam adalah mencakup: (1) penghapusan bunga dan pembaharuan aktivitas bank agar sesuai prinsip Islam; (2) distribusi pendapatan dan kekayaan yang wajar; dan (3) mencapai kemajuan pembangunan ekonomi. Sedangkan dalam perspektif stakeholder, menurut Dusuki (2008, dalam Falikhatun dan Assegaf, 2012:248) tujuan Islamic Bank adalah memaksimalkan laba, kontribusi pada kesejahteraan sosial, mengurangi kemiskinan, mempromosikan proyek pembangunan berkesinambungan, meminimalkan biaya operasi, meningkatkan kualitas produk dan jasa, menyediakan produk keuangan yang layak dan kompetitif dan mempromosikan nilai-nilai Islam dan way of life melalui staf, klien, dan masyarakat umum.

Hameed et. al., (2004) merumuskan Islamicity Performance Index untuk mengukur kinerja perbankan syariah dari segi tujuan syariah, sehingga dapat diketahui apakah kinerja perbankan telah sesuai dengan prinsip-prinsip syariah. Dalam penelitian ini, peneliti menggunakan profit sharing ratio, zakat performance ratio dan equitable distribution ratio yang merupakan rasio-rasio dalam islamicity performance index. 


\section{Profit Sharing Ratio}

Profit sharing (bagi hasil) merupakan salah satu tujuan utama dari perbankan syariah. Oleh karena itu sangat penting untuk mengetahui seberapa jauh perbankan syariah telah berhasil mencapai eksistensi mereka atas bagi hasil melalui profit sharing ratio (Hameed et. al., 2004:18). Profit sharing ratio dihitung dengan menjumlahkan pembiayaan dari akad mudharabah dan musyarakah yang selanjutnya dibandingkan dengan total pembiayaan. Berikut rumus profit sharing ratio (PSR):

$$
\text { PSR }=\frac{(\text { Mudharabah }+ \text { Musyarakah })}{\text { Total Pembiayaan }}
$$

\section{Zakat Performance Ratio}

Zakat merupakan salah satu perintah dalam Islam sehingga harus menjadi salah satu tujuan akuntansi syariah. Oleh karena itu, kinerja perbankan syariah harus didasarkan pada zakat yang dibayarkan oleh bank untuk menggantikan indikator kinerja konvensional yaitu earning per share. Kekayaan bank harus didasarkan pada aset bersih dari pada laba bersih yang ditekankan oleh metode konvensional. Sehingga apabila bank memiliki aset bersih yang tinggi, maka semakin tinggi pula zakat yang harus dibayarkan (Hameed et. al., 2004:19). Adapun rumus zakat performance ratio (ZPR) sebagai berikut:

$$
\mathrm{ZPR}=\frac{\text { Zakat }}{\text { Net Asset }}
$$

\section{Equitable Distribution Ratio}

Akuntansi syariah berusaha memastikan distribusi yang merata kepada semua pihak selain kegiatan bagi hasil. Distribusi bagi hasil dari pendapatan yang diperoleh bank-bank syariah inilah yang pada dasarnya coba untuk ditemukan oleh rasio ini kepada berbagai pihak pemangku kepentingan (Hameed et. al., 2004:19). Rasio ini dihitung dengan menjumlahkan dana yang dikeluarkan untuk qardh dan dana kebajikan, upah karyawan, pemegang saham dan laba bersih. 
Untuk setiap item, akan dihitung jumlah yang didistribusikan dari total pendapatan setelah dikurangi zakat dan pajak. Berikut rumus equitabel distribution ratio:

$\begin{array}{lll}\text { 1. } \text { Qardh \& Donation } & = & \frac{\text { Loans \& Donations }}{\text { Revenue }-(\text { Zakat }+ \text { Tax })} \\ \text { 2. Employees Expense } & = & \frac{\text { Labor Costs }}{\text { Revenue }-(\text { Zakat }+ \text { Tax })} \\ \text { 3. Shareholders } & = & \frac{\text { Deviden }}{\text { Revenue }-(\text { Zakat }+ \text { Tax })} \\ \text { 4. Net Profit } & = & \frac{\text { Net Income }}{\text { Revenue }-(\text { Zakat }+ \text { Tax })}\end{array}$

\section{Kinerja Keuangan}

Kinerja keuangan merupakan salah satu tolak ukur yang bisa digunakan untuk mengetahui keberhasilan suatu perusahaan dalam menjalankan bisnisnya. Untuk mengetahui keadaan kinerja keuangan perusahaan, para stakeholders biasanya akan melakukan analisis menggunakan rasio keuangan. Terdapat berbagai analisis rasio keuangan yang dapat dilakukan dengan melihat laporan keuangan, salah satunya adalah dengan rasio profitabilitas. Return on Assets (ROA) adalah salah satu rasio profitabilitas yang mengukur seluruh efektifitas manajemen dalam memanfaatkan aset yang ada untuk menghasilkan profit. Menurut Keown et al. (2008:80): "ROA menentukan jumlah pendapatan bersih yang dihasilkan dari aset-aset perusahaan dengan menghubungkan pendapatan bersih ke total aset" ROA secara statistik signifikan untuk menjelaskan konstruk kinerja perusahaan yang dalam ini berposisi sebagai variabel terikat, dimana variabel bebasnya adalah intellectual capital (Ulum et. al., 2008:20). ROA dihitung dengan cara membandingkan seluruh laba perusahaan sebelum dikurangi bunga dan pajak (EBIT) dengan keseluruhan aset yang dimiliki perusahaan. Berikut rumus dari ROA:

$$
\text { ROA }=\frac{\text { EBIT }}{\text { Total Assets }}
$$




\section{Hipotesis}

Hipotesis merupakan jawaban terhadap rumusan masalah penelitian. Berdasarkan landasan teori dan penelitian terdahulu, maka hipotesis yang diajukan dalam penelitian ini adalah sebagai berikut:

$\mathrm{H}_{1}$ : Intellectual capital berpengaruh positif terhadap return on assets (ROA) Bank Umum Syariah pada periode 2010-2014.

$\mathrm{H}_{2}$ : Profit sharing ratio berpengaruh positif terhadap return on assets (ROA) Bank Umum Syariah pada periode 2010-2014.

$\mathrm{H}_{3}$ : Zakat performance ratio berpengaruh positif terhadap return on assets (ROA) Bank Umum Syariah pada periode 2010-2014.

$\mathrm{H}_{4}$ Equitable distribution ratio berpengaruh positif terhadap return on assets (ROA) Bank Umum Syariah pada periode 2010-2014.

$\mathrm{H}_{5}$ : Intellectual capital, profit sharing ratio, zakat performance ratio dan equitable distribution ratio secara simultan berpengaruh terhadap return on assets (ROA) Bank Umum Syariah pada periode 2010-2014.

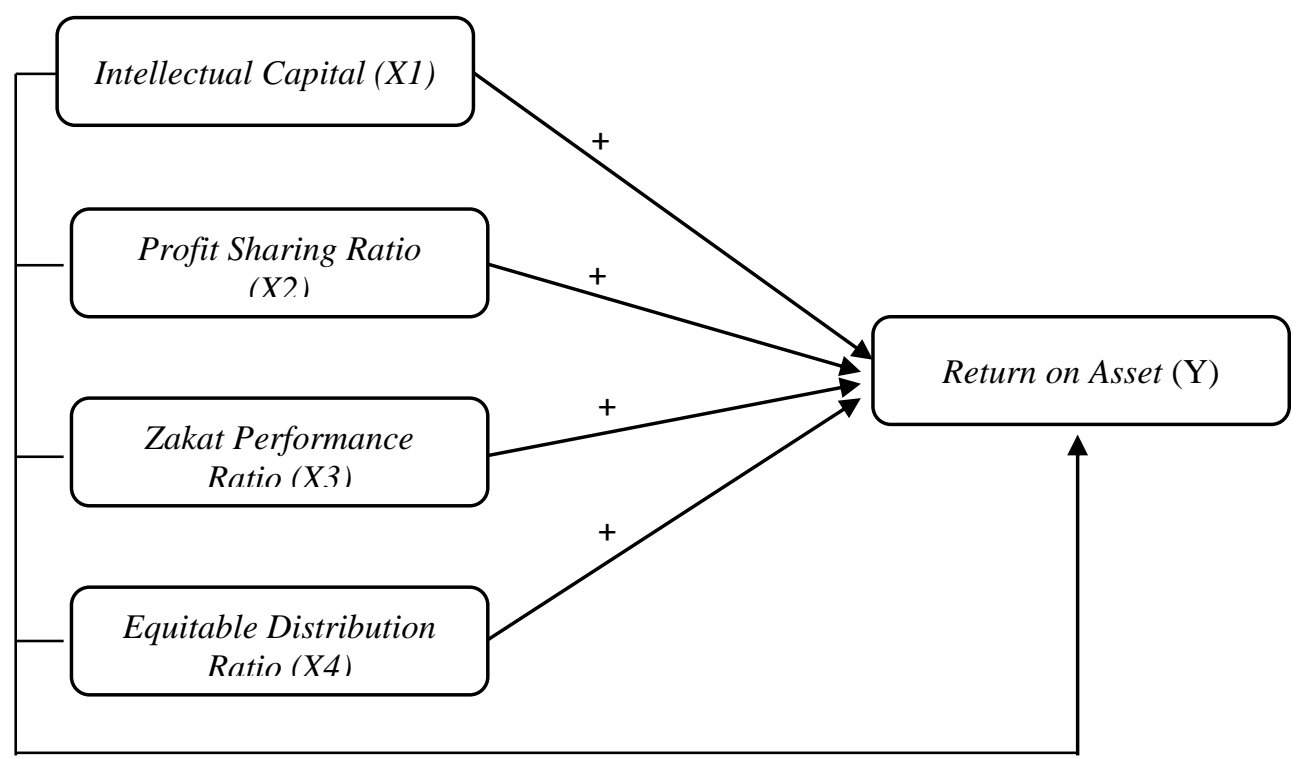

\section{Gambar II.1 Bagan Kerangka Teoretik}

Sumber: Data diolah Peneliti (2016) 


\section{METODE PENELITIAN}

Populasi dalam penelitian ini adalah 11 Bank Umum Syariah yang terdaftar di Bank Indonesia. Penelitian ini menggunakan seluruh populasi sebagai objek penelitian dikarenakan sedikitnya jumlah populasi yang tersedia. Metode analisis yang digunakan adalah analisis regresi data panel karena observasi yang digunakan dalam penelitian ini terdiri atas beberapa perusahaan (cross section) dan beberapa tahun (time series). Model persamaan regresi yang digunakan adalah sebagai berikut:

$$
R O A_{i t}=\beta_{0}+\beta_{1} V A I C_{i t}+\beta_{2} P S R_{i t}+\beta_{3} Z P R_{i t}+\beta_{4} E D R_{i t}+\mathrm{e}_{\mathrm{it}}
$$

\section{HASIL DAN PEMBAHASAN}

\section{Statistik Deskriptif}

Tabel IV.1. Descriptive Statistics

\begin{tabular}{lccccc}
\hline & ROA & VAIC & PSR & ZPR & EDR \\
\hline Mean & 0.011784 & 1.704627 & 0.308214 & 0.000182 & 0.236667 \\
Maximum & 0.038000 & 7.187000 & 0.865400 & 0.001000 & 0.660000 \\
Minimum & -0.025000 & -23.32700 & 0.000000 & 0.000000 & 0.020000 \\
Std. Dev. & 0.011357 & 3.961335 & 0.191500 & 0.000249 & 0.170572 \\
Observations & 51 & 51 & 51 & 51 & 51
\end{tabular}

Sumber: Data diolah oleh peneliti menggunakan Eviews 7

Standar deviasi ROA selama periode penelitian sebesar 1,14\%. Hal tersebut menunjukkan hasil yang baik karena standar deviasi yang mencerminkan penyimpangan dari data tersebut lebih kecil daripada nilai rata-ratanya yaitu sebesar 1,18\%. Nilai ROA tertinggi dimiliki oleh PT. Bank Mega Indonesia Syariah pada tahun 2012 sebesar 3,8\%. Pada tahun 2012 laba bersih Bank Mega Syariah naik secara signifikan 243\% dari Rp 53.867 miliar pada akhir tahun 2011 menjadi Rp 184.872 miliar rupiah pada akhir tahun 2012. Sedangkan nilai ROA terendah dimiliki oleh PT. Bank Panin Syariah pada tahun 2010 sebesar -2,5\%. Tahun 2010 merupakan tahun pertama atau masa awal beroperasinya Bank Panin Syariah di Indonesia setelah mengakuisisi Bank Harfa pada Desember 2009. 
Beban operasional yang tinggi diawal beroperasinya bank, dimana pada saat awal pendirian bank belum memiliki aset produktif yang cukup untuk menutupi beban operasional menjadi penyebab rendahnya nilai ROA pada tahun ini.

Standar deviasi VAIC ${ }^{\text {TM }}$ selama periode penelitian adalah sebesar 3,961. Hal tersebut menunjukkan hasil yang kurang baik karena standar deviasi yang mencerminkan penyimpangan dari data tersebut lebih besar dari 1,705 sebagai nilai rata-ratanya. Nilai tertinggi VAIC ${ }^{\text {TM }}$ adalah sebesar 7,187 dimiliki oleh PT. Bank Maybank Syariah Indonesia pada tahun 2014. Pada tahun 2014 pendapatan dari penyaluran dana dan pendapatan operasional lainnya Bank Maybank Syariah mengalami peningkatan. Sedangkan nilai terendah VAIC ${ }^{\text {TM }}$ adalah -23,33 yang dimiliki oleh PT. Bank Victoria Syariah pada tahun 2014. Pada tahun tersebut, Non Performing Financing (NPF) Maybank Syariah cukup tinggi yaitu sebesar $7,10 \%$, sehingga menyebabkan bank mengalami kerugian yang cukup besar.

Standar deviasi yang dimiliki PSR adalah sebesar 19,15\%. Angka tersebut menunjukkan hasil yang baik karena standar deviasi yang mencerminkan penyimpangan dari data tersebut lebih kecil daripada nilai rata-ratanya yaitu sebesar 30,8\%. Nilai tertinggi dari PSR adalah sebesar 86,5\% yang dimiliki oleh PT. Bank Panin Syariah pada tahun 2014. Pada akhir tahun 2014 pembiayaan bank melalui akad musyarakah mengalami peningkatan secara signifikan yaitu sebesar $371 \%$. Sedangkan nilai terendah PSR adalah 0 yang dimiliki oleh PT. Bank Maybank Syariah Indonesia pada tahun 2012 dan 2013. Pada tahun tersebut, Maybank Syariah belum memiliki produk pembiayaan dengan akad mudharabah dan pada tahun 2012 bank juga baru mengembangkan produk pembiayaan dengan akad musyarakah.

Standar deviasi ZPR selama periode penelitian adalah sebesar 0,025\% atau menunjukkan hasil yang kurang baik karena standar deviasi yang mencerminkan penyimpangan dari data tersebut lebih besar dari nilai rata-ratanya yaitu sebesar $0,018 \%$. Nilai tertinggi dari ZPR adalah sebesar $0,1 \%$ yang dimiliki oleh PT. Bank Mega Syariah pada tahun 2012. Meningkatnya aset dan laba bersih perusahaan diikuti meningkatnya zakat yang dikeluarkan perusahaan menjadi salah satu penyebab meningkatnya nilai ZPR. Sedangkan nilai terendah ZPR 
adalah 0 atau tidak sama sekali mengeluarkan zakat. PT. Bank BNI Syariah pada tahun 2010, PT. Bank BCA Syariah tahun 2010 dan 2014, PT. Bank Victoria Syariah tahun 2013 dan 2014, PT. Bank Panin Syariah tahun 2010-2013, PT. Bank Maybank Syariah Indonesia tahun 2012-2014, PT. Bank Jabar dan Banten Syariah tahun 2010-2012 dan 2014, dan PT. Bank Bukopin Syariah pada tahun 2010-2014. Sebagian besar bank-bank yang tidak mengeluarkan zakatnya pada tahun-tahun tertentu, mereka hanya bertindak sebagai penerima dana zakat dari pihak luar bank dan selanjutnya akan mereka salurkan kepada masyarakat yang membutuhkan.

Nilai standar deviasi EDR adalah sebesar 17\%. Hal tersebut menunjukkan hasil yang baik karena standar deviasi yang mencerminkan penyimpangan dari data lebih kecil dari nilai rata-ratanya yaitu sebear 23,67\%. Nilai tertinggi dari EDR adalah sebesar 0,66 atau sebesar $66 \%$ yang dimiliki oleh PT. Bank BRI Syariah pada tahun 2011. Meningkatnya total pendapatan yang diikuti oleh meningkatnya penyaluran dana melalui produk pembiayaan Qard menjadi salah satu penyebab meningkatnya nilai EDR BRI Syariah. Sedangkan nilai terendah EDR adalah sebesar 0,02 atau sebesar 2\% yang dimiliki oleh PT. Bank Panin Syariah pada tahun 2010. Rendahnya total pendapatan yang berdampak pada kerugian yang didapatkan Bank Panin Syariah pada tahun 2010 menjadi penyebab rendahnya nilai EDR pada tahun tersebut.

\section{Uji Chow}

Tabel IV.2. Hasil Uji Chow

\begin{tabular}{lc}
\hline & Probability \\
\hline Cross-section Chi-square & 0.0000 \\
\hline Sumber: Data diolah peneliti dengan menggunakan Eviews 7
\end{tabular}

Uji Chow dilakukan dalam memilih model antara Common Effect dan Fixed Effect. Tabel IV.2 menunjukkan bahwa uji Chow menghasilkan nilai probabilitas chi-square sebesar 0.0000. Nilai tersebut berada di bawah 0.05, maka $\mathrm{H}_{0}$ ditolak dan $\mathrm{H} 1$ diterima. Hasil tersebut menunjukkan bahwa data yang digunakan dalam observasi merupakan data panel dan pendekatan yang digunakan 
untuk meregresi data panel adalah fixed effect, sehingga pengujian akan dilanjutkan ke uji Hausman.

\section{Uji Hausman}

Tabel IV.3. Hasil Uji Hausman

\begin{tabular}{lc}
\hline & Probability \\
\hline Cross-section random & 0.0276 \\
\hline Sumber: Data diolah oleh penulis menggunakan E-views 7
\end{tabular}

Uji Hausman dilakukan untuk memilih model persamaan antara Fixed Effect atau Random Effect. Tabel IV.3 menunjukkan bahwa uji Hausman menghasilkan nilai probabilitas chi-square sebesar 0.0276. Nilai probablitas chisquare tersebut lebih kecil dari 0.05 , sehingga hipotesis $\mathrm{H}_{0}$ ditolak dan menerima $\mathrm{H}_{1}$, berarti model regresi yang digunakan adalah Fixed Effect.

\section{Uji Normalitas}

Residual data dapat dikatakan normal apabila memiliki nilai signifikansi (2-tailed) lebih besar dari 0,05. Hasil dari uji normalitas dengan menggunkan uji Kolmogorov-Smirnov dengan menggunakan Sofware IBM SPSS 20 dapat dilihat pada tabel IV.4.

Tabel IV.4. Hasil Uji Kolmogorov-Smirnov

\begin{tabular}{lc}
\hline & $\begin{array}{c}\text { Unstandardized } \\
\text { Residual }\end{array}$ \\
\hline Asymp Sig. (2-tailed) & 0.532 \\
\hline Sumber: Data diolah oleh penulis menggunakan IBM SPSS 20
\end{tabular}

Tabel di atas menunjukkan bahwa residual data pada penelitian ini dapat dikatakan normal, karena nilai signifikansi (2-tailed) adalah 0,0532 atau lebih besar dari 0,05 .

\section{Uji Multikolinearitas}

Multikolinearitas dalam sebuah model dapat dilihat apabila korelasi antar dua variabel memiliki nilai di atas 0,8 (rule of thumb). Hasil dari uji multikolinieritas dengan menggunakan Eviews 9 dapat dilihat pada tabel IV.5. 
Tabel IV.5. Hasil Uji Multikolinieritas

\begin{tabular}{crrrr}
\hline & VAIC & \multicolumn{1}{c}{ PSR } & \multicolumn{1}{c}{ ZPR } & \multicolumn{1}{c}{ EDR } \\
\hline VAIC & 1.000000 & -0.368594 & 0.193615 & 0.169455 \\
PSR & -0.368594 & 1.000000 & -0.380692 & -0.214463 \\
ZPR & 0.193615 & -0.380692 & 1.000000 & 0.289080 \\
EDR & 0.169455 & -0.214463 & 0.289080 & 1.000000
\end{tabular}

Sumber: Data diolah peneliti dengan menggunakan Eviews 9

Tabel di atas menunjukkan bahwa tidak ada koefisien korelasi antar variabel bebas yang memiliki nilai lebih besar dari 0.8 atau mendekati 1 , sehingga tidak terdapat multikolinieritas pada sampel perusahaan manufaktur.

\section{Hasil Regresi Data Panel}

Tabel IV.6. Hasil Regresi Data Panel

\begin{tabular}{ccc}
\hline Variable & Coefficient & Prob. \\
\hline C & 0.011224 & 0.0176 \\
VAIC & 0.001142 & 0.0011 \\
PSR & -0.029126 & 0.0235 \\
ZPR & 32.21526 & 0.0000 \\
EDR & 0.006529 & 0.3894 \\
Adjusted R-squared & & 0.7293 \\
Prob (F-Statistic) & & 0.0000 \\
\hline
\end{tabular}

Sumber: Data diolah oleh penulis menggunakan E-views 9

Berdasarkan pada tabel IV.6, persamaan regresi yang menunjukkan pengaruh variabel independen yaitu intellectual capital (VAIC), profit sharing ratio (PSR), zakat performance ratio (ZPR) dan equitable distribution ratio (EDR) terhadap variabel dependen return on assets (ROA) adalah:

$$
\begin{gathered}
\mathrm{ROA}=0,011224+0,001142 \mathrm{VAIC}-0,029126 \mathrm{PSR}+32,21526 \mathrm{ZPR}+ \\
0,006529 \mathrm{EDR}+\mathrm{e}
\end{gathered}
$$

Variabel intellectual capital yang diproksikan oleh value added intellectual coefficient (VAIC ${ }^{\mathrm{TM}}$ ) yang memiliki nilai koefisien sebesar 0,001142 dengan probabilitas sebesar 0,0011. Hal ini menunjukkan bahwa intellectual capital berpengaruh positif terhadap kinerja. Jadi semakin tinggi intellectual capital maka semakin meningkat pula kinerja bank umum syariah. Sebaliknya, semakin rendah intellectual capital dari bank umum syariah maka akan semakin rendah pula kinerjanya. Sesuai dengan resource based theory yang menyatakan bahwa perusahaan yang mampu mengelola sumber daya intelektualnya dengan baik dapat menghasilkan nilai tambah dan keunggulan kompetitif, sehingga akan 
meningkatkan kinerja keuangan perusahaan. Hasil penelitian ini sesuai dengan penelitian yang dilakukan oleh Ulum et al. (2008), Rambe (2012), Karimi et al. (2015) dan Kamath (2015) yang menyatakan bahwa intellectual capital berpengaruh positif dan signifikan terhadap ROA.

Variabel profit sharing ratio (PSR) memiliki nilai koefisien sebesar 0,02912 dan probabilitas sebesar 0.0235. Hasil tersebut disebabkan karena sumbangan kenaikan pendapatan bagi hasil yang diperoleh dari penyaluran profit sharing untuk menghasilkan laba tidak sebanding dengan peningkatan investasi (aset) bank umum syariah. Meningkatnya presentase nilai NPF (Non Performing Financing) pada tahun 2013 dan 2014 menjadi salah satu penyebab tidak sebandingkanya peningkatan laba dengan peningkatan investasi bank umum syariah. Hasil penelitian ini tidak sesuai dengan stakeholders theory yang menyatakan bahwa perusahaan akan mampu menjaga kinerja dan menjaga keberlangsungan hidup perusahaan dengan cara mengakomodasi keinginan dan kebutuhan stakeholders. Hasil penelitian ini juga tidak sesuai dengan penelitian yang dilakukan oleh Falikhatun dan Assegaf (2012) dan Puspasari dan Mawardi (2014) yang menyatakan bahwa PSR berpengaruh positif terhadap ROA

Variabel zakat performance ratio (ZPR) memiliki nilai koefisien sebesar 32,215 dan probabilitas sebesar 0.0000. Jadi semakin tinggi bank umum syariah membayar zakat, maka akan meningkatan kinerja mereka. Sebaliknya semakin rendah mereka membayar zakat, maka akan menurunkan kinerja mereka. Stakeholders theory menyatakan bahwa semua stakeholders memiliki hak untuk diperlakukan dengan adil oleh perusahaan, sehingga akan menjaga hubungan baik perusahaan dengan para stakeholder. Ketika perusahaan mampu memperhatikan dan menjaga hubungannya dengan stakeholder, maka perusahaan akan mendapatkan dukungan dan citra positif dari stakeholder dalam menjalankan bisnis yang nantinya akan berdampak pada peningkatan kinerja dan keberlangsungan hidup perusahaan (Fahrizqi, 2010:14). Hasil penelitian ini sesuai dengan penelitian yang dilakukan oleh Maisaroh (2015) dan Puspasari dan Mawardi (2014) yang menyatakan bahwa ZPR berpengaruh positif dan signifikan terhadap ROA. 
Variabel equitable distribution ratio (EDR) memiliki nilai koefisien sebesar 0,006529 dan probabilitas sebesar 0.3894. Jadi dapat disimpulkan bahwa EDR berpengaruh positif tidak signifikan terhadap kinerja. Hasil tersebut disebabkan karena sebagian besar Bank Umum Syariah (BUS) di Indonesia mendistribusikan pendapatannya lebih besar pada karyawan dan perusahaan sendiri. Sedangkan untuk masyarakat dan pemegang saham hanya sebagian kecil dari pendapatannya yang didistribusikan pada mereka. Stakeholders theory menyatakan bahwa ketika perusahaan mampu mendistribusikan pendapatannya pada stakeholder dengan merata dan adil, berarti perusahaan telah mampu mengakomodasi keinginan dari stakeholder. Sehingga akan menghasilkan hubungan yang harmonis antara perusahaan dan stakeholder yang akan berdampak pada perusahaan dapat menjaga kinerja dan kelangsungan bisnisnya. Hasil penelitian ini sesuai dengan penelitian yang dilakukan oleh Maisaroh (2015) yang membuktikan bahwa EDR berpengaruh positif tidak signifikan terhadap ROA.

Untuk mengetahui pengaruh variabel bebas (VAIC, PSR, ZPR dan EDR) secara bersama-sama terhadap variabel terikat (ROA) maka digunakan uji F. Penentuan hasil hipotesis dapat dilihat dari nilai F-Stat $<0,05$ maka variabelvariabel bebas berpengaru terhadap variabel terikat. Dalam penelitian ini, nilai probabilitas F-Stat adalah sebesar 0,000 atau lebih kecil dari 0,05 maka dapat disimpulkan bahwa VAIC, PSR, ZPR, dan EDR secara simultan berpengaruh terhadap kinerja bank umum syariah.

\section{Koefisien Determinasi}

Koefisien determinasi dalam penelitian ini dapat dilihat dari adjusted RSquared pada tabel IV.6 yaitu sebesar 0,729337. Nilai koefisien tersebut menunjukkan bahwa sebesar $72,93 \%$ variabel terikat yaitu return on assets (ROA) dapat dijelaskan oleh variabel bebas yaitu intellectual capital, profit sharing ratio, zakat performance ratio, dan equitable distribution ratio. Sedangkan 27,07\% sisanya dijelaskan oleh faktor-faktor lain diluar variabel penelitian ini. 


\section{KESIMPULAN DAN SARAN}

\section{Kesimpulan}

Penelitian ini meneliti tentang pengaruh intellectual capital, profit sharing ratio, zakat performance ratio, dan equitable distribution ratio terhadap return on assets pada Bank Umum Syariah periode 2010-2014. Kesimpulan yang dapat diambil dari hasil penelitian ini adalah:

1. Intellectual capital memiliki pengaruh positif dan signifikan terhadap ROA. Hasil ini menunjukkan bahwa semakin baik bank umum syariah mendayagunakan intellectual capital yang dimiliki maka akan meningkatkan kinerja keuangannya.

2. Profit sharing ratio memiliki pengaruh negatif signifikan terhadap ROA. Artinya semakin tinggi nilai profit sharing ratio, maka akan menurunkan nilai dari ROA. Hasil ini menunjukkan bahwa pembiayaan bank umum syariah melalui akad mudharabah dan musyarakah belum efektif dalam menciptakan laba bank.

3. Zakat performance ratio memiliki pengaruh positif dan signifikan terhadap ROA. Hasil ini menunjukkan bahwa bank umum syariah dengan tingkat pembayaran zakat yang tinggi cenderung akan memperoleh laba yang tinggi pula, sehingga akan meningkatkan kinerja bank umum syariah.

4. Equitable distribuiton ratio memiliki pengaruh positif dan tidak signifikan terhadap ROA. Hasil ini menunjukkan bahwa equitable distribution ratio tidak menentukan dalam peningkatan kinerja bank umum syariah.

5. Intellectual capital, profit sharing ratio, zakat performance ratio dan equitable distribution ratio secara bersama-sama memiliki pengaruh terhadap ROA.

\section{Saran}

Berdasarkan hasil penelitian yang telah dilakukan, maka saran yang dapat diberikan oleh peneliti adalah: 
1. Penelitian selanjutnya diharapkan dapat menggunakan indikator lain dari islamicity performance index seperti director-employees welfare ratio dan islamic income vs non-islamic income, dan menggunakan rasio keuangan lainnya sebagai proksi kinerja perbankan syariah. Sehingga dalam penelitian selanjutnya dapat menghasilkan variasi dalam menjelaskan implementasi prinsip-prinsip syariat Islam dalam mempengaruhi kinerja perbankan syariah.

2. Penelitian selanjutnya hendaknya memperpanjang periode penelitian, memperluas ukuran populasi dengan menambahkan Unit Usaha Syariah (UUS) dan Bank Pembiayaan Rakyat Syariah (BPRS) sebagai sampel dalam penelitian.

\section{DAFTAR PUSTAKA}

Anshori, Abdul G. Perbankan Syariah di Indonesia. Yogyakarta: Gadjah Mada University Press. 2007.

Daud, Rulfah M., dan A. Amri. Pengaruh Intellectual Capital dan Corporate Social Resoponsibility Terhadap Kinerja Perusahaan (Studi Empiris pada Perusahaan Manufaktur di Bursa Efek Indonesia). Jurnal Telaah \& Riset Akuntansi. 2008, Vol. 1, No. 2, hh. 213-231.

Fahrizqi, Anggara. Faktor-Faktor Yang Mempengaruhi Pengungkapan Corporate Social Responsibility Dalam Laporan Tahunan Perusahaan. Skripsi Universitas Diponegoro. 2010.

Falikhatun dan Y. U. Assegaf. Bank Syariah Di Indonesia: Ketaatan Pada PrinsipPrinsip Syariah dan Kesehatan Fiansial. CBAM-FE UNISSULA. 2012, Vol. 1, No. 1, hh. 245-254

Fitriyeni, Radhiyatul, dan Yurniwati. The Analysis of Intellectual Capital Performance of Islamic Bank in Indonesia. Global Journal of Business and Social Science Review. ISSN: 2289-8506. 2015, Vol. 3, No. 1, hh. 211218. 
Gitman, L. J., dan C. J. Zutter. Principles of Managerial Finance 13th Global Edition. US: Pearson. 2011

Hameed, Shaul et. al. 2004. Alternative Disclosure \& Performance Measures For Islamic Bank. www.iium.edu.my diakses tanggal 29 April 2016.

Hermawan, Hery, dan Fatchur Rochman. Aplikasi Teori Stakeholder: Pengaruhnya Terhadap Pengungkapan Risiko Pada Perusahaan Manufaktur Yang Terdaftar Di BEI. Jurnal Akademika. 2015, Vol. 18, No. 1, hh. 71-80.

Kamath, G. Bharathi. Impact of Intellectual Capital on Financial Performance and Market Valuation of Firms in India. International Letters of Social and Humanistic Sciences. ISSN: 2300-2697. 2015, Vol. 48, hh. 107-122.

Karimi, Edris, et. al. An Empirical On The Relationship Between Intellectual Capital And Financial Performance Of Tehran Stock Exchange Listed Companies. Technical Journal of Engineering and Applied Sciences. ISSN: 2051-0853. 2015.

Keown, A. J., J.D. Martin, dan D. F. Scott. Manajemen Keuangan: Prinsip dan Penerapan Edisi 10. Diterjemahkan Oleh M. P. Widodo. Indonesia: PT. Indeks. 2008.

Maisaroh, Siti. Pengaruh Intellectual Capital dan Islamicity Performance Index Terhadap Profitability Perbankan Syariah Indonesia. Jurnal Fakultas Ekonomi UIN Malang. 2015.

Melani, Erlin., dan Endah Suwarni. Tren Pengungkapan Intellectual Capital Industri Perbankan: Sebuah Bukti Empiris di Indonesia. Jurnal Keuangan dan Perbankan. 2013, Vol. 17, No. 2, hh. 279-291.

Motilewa, Bolanle D., O. A. Onakoya, dan A. O. Oke. ICT and Gender Specific Challenge Faced by Female Entrepreneurs in Nigeria. International Journal of Businsess and Social Science. 2015, Vol. 6. No. 3, hh. 97-105. 
Prasetiyo, Luhur. Corporate Social Responsibility Bank Syariah Di Indonesia. Kodefikasia. 2014, Vol. 8, No. 1.

Puspasari, Rosana dan Imron Mawardi. Pengaruh Kinerja Sosial Terhadap Profitabilitas Bank Syariah. JESTT. 2014, Vol. 1, No. 7, hh. 456-468.

Rambe, Rizki Fillhayati. Pengaruh Intellectual Capital Terhadap Kinerja Keuangan Perusahaan Perbankan Yang Terdaftar Di BEI. Jurnal Keuangan dan Bisnis. 2012, Vol. 4, No. 3.

Sangkala. Intellectual Capital Management: Strategi Baru Membangun Daya Saing Perusahaan. Jakarta: YAPENSI. 2006.

Sawarjuwono, Tjiptohadi, dan Agustine P. Kadir. Intellectual Capital: Perlakuan, Pengukuran dan Pelaporan (Sebuah Library Research). Jurnal Akuntansi \& Keuangan. 2003, Vol. 5, No. 1, hh. 35-57.

Ulum, Ihyaul, Imam Ghozali dan Anis Chariri. Intellectual Capital dan Kinerja Keuangan Perusahaan: Suatu Analisis Dengan Pendekatan Partial Least Squares. Simposium Nasional Akuntansi XI Pontianak. 2008.

Winarno, Wing Wahyu. Analisis Ekonometrika dan Statistika dengan Eviews. Yogyakarta: UPP STIM YKPN. 2009. 